\title{
Cultural Diversity in Higher Education Benefits and Challenges
}

\author{
${ }^{1}$ Dr. Syed Asad Abbas Rizvi, \\ ${ }^{2}$ Dr. Syed Manzar Abbas Naqvi, ${ }^{\mathbf{3}}$ Mehwish Batool
}

\section{Abstract}

Diversity is a symbol of life everywhere including educational settings. The present study was aimed to find out the benefits and challenges for inclusion of diversity in higher education. It was a qualitative study, and document analysis was used as method of inquiry .The population comprises selected documents related to cultural diversity in higher education. Theoretical sampling was used as sampling method. It was found that there were many advantages of diversity including students satisfaction and inter and intra-cultural acceptance. It was also found that the biggest challenge for diversity its acceptance. The biggest challenges are its acceptance and taking it as a burden. It was recommended that there is a need for acceptance of Diversity at all levels and inclusion of multicultural education in teacher education program.

\section{Keywords: Culture, Diversity, Higher Education}

\section{Introduction}

Education plays a vital role in existence and development of a nation. Higher education is now a major concern for all the stakeholders of education. That is why there is more focus on its expansion, in terms of human and material capital. Multi-mode universities and online learning is the result of this expansion. Besides this, there are some dimensions which are neglected in the process of expansion. Considering and focusing Cultural diversity is one of them. This paper describes the importance need and status of cultural diversity in higher education in general and in Pakistan in specific. One of the challenges for universities since last two decades was how to meet with increasing demands of university students belongs to different cultural settings and ethnic groups.

Many changes pressured institutions to incorporate educational equity for the greater good of our society (Ibarra, 1999). Beside these efforts, there are many student which were remain underrepresented, in different fields of study and the problem becomes worst and complicated. The universities are facing a problem that they are unable to find out the correct direction to move that satisfy all segments of the society. (Florio, 1994).

\footnotetext{
${ }^{1}$ Assistant Professor, Department of Education, IIUI Email: drasad.rizvi@iiu.edu.pk

${ }^{2}$ Assistant Professor, Leads Lahore University, Lahore

${ }^{3}$ Research Scholar, University of Sargodha
} 


\subsection{Statement of the Problem}

There are lot of evidences that those institutions which emphasize peopleoriented relationships, group work and collaborative teaching and learning environments, focused on society demands and requirements. These are not only beneficial for low represented populations, but they also provide conditions to achieve academic and personal success in fields where they have been unsuccessful in the past (Bowen \& Bok, 1998). In this condition, it was necessary to find out the existing conditions and associated challenges with the inclusion of cultural diversity in higher education. Therefore the problem to be investigated is "What are the benefits and challenges related to cultural diversity faced by higher education institutions?"

\subsection{Objectives of the Study}

The objectives of the study were

1. To investigate the aims and objectives of multicultural education in universities.

2. To find out the benefits of inclusion of diversity in higher education

3. To explore the challenges of inclusion of diversity in higher education

\subsection{Significance of the Study}

The study is significant for different stakeholders for example

1. It would be helpful for teachers of higher education institutions to understand the concept of diversity and apply in actual classroom teaching

2. The study would be significant for university leadership and administrative officers to understand benefits of inclusion cultural diversity in higher education

3. The study would be helpful for university administrators to analyze the existing conditions of cultural diversity in higher education.

\section{Research Methodology}

It was a quantitative study. Document analysis was used as a method of analysis. Document or Documentary analysis is a social research method and is an essential research tool and is an invaluable part of most schemes of triangulation. Documentary work involves reading lots of written material (Frankel, 2009).

In this research, written text was used to analyze the data. The most significant advantage of conduction document analysis is that it provides a guideline for a framework which is the principle focus of the research. Heffernan (2012) suggest different types of analysis. From these Semiotics Analysis was chosen as the analysis method. Semiotics is a science that studies the signs. 


\subsection{Population and sampling}

The population comprises all relevant documents and articles on diversity in education. For this study, Theoretical sampling was used as method of sampling.

\subsection{Data Analysis}

The Data was analyzed by semiotic analysis. The semiotic analysis is used a lot in media analysis but now it is also used in education. It is different from the content analysis in the way it focuses on the symbols present in the content. It is more focus on meaning.

\section{Findings}

\subsection{Aims and objectives of Multicultural Education}

The first objective was to find out the aims and objectives of multicultural education in universities. In this regard, it was found that

1. There is no agreement of experts on this issue. Educational philosophers demanded for maintaining and developing of group culture, fostering child's development of autonomy and introducing him to new and different ideas. This exposure would assist children in thinking, and encourage them to have a more open mindset (Levinson, 2009).

2. On the other hand the theorist was in the favor of developing a model of multicultural education, which warrants social action in an acceptable manner. They argued that, students are equipped with knowledge, values, skills, attitudes, behaviors, necessary to evoke in societal changes. Teachers, in this model would serve as agents of change in student's knowledge, skills, and attitudes (Sleeter \& Grant, 2007).

3. According to Levinson (2009), Multicultural education has many goals like promoting good citizenship skills acceptance, correction in historical record, Increase Self-esteem of non-mainstream students, Promote Social Justice and Equity, Enable students to succeed in an integrated, multicultural world.

4. According to Banks (1995) one of the major aims of multicultural education is preserving minority group culture. In this regard, it is necessary to provide a good sensitivity training of all members of the Institute and separate units on ethnic celebrations and closer attention paid to prejudice (Banks, 1995).

5. Levinson (2009) stated that Multicultural education may have many objectives span beyond autonomy, exposing students to global uniqueness, fostering deepened understanding, and providing access to different practices, and ways of life (Levinson, 2009).

This is only a glimpse of aims and objectives. The main aim of including cultural diversity in educational setting is to broader the mindset of students and teachers as well. 


\subsection{Benefits of Diversity in Higher Education}

There are a number of studies that discuss the benefits of diversity in higher education. They were varying in objectives, methods, tools and techniques used in data analysis. Here are examples of these studies.

1. Students' involvement in diversity experiences during college had significant positive effects on their scores on the CAAP Critical thinking test (Pascarella et al., 2001).

2. The results from the study (Chang 1999)) indicated that diversity has a positive effect on educational outcomes through its effects on diversityoriented student activities and experiences (Chang, 1999). It provides the broader and improved mission of the Institute.

3. Association of American Universities (1997) demanded for diversity in universities. They argued that most of the students get benefit from an education that takes place within diverse cultural settings.

4. According to Association of American Universities "as we seek to prepare students for life in the twenty-first century, the educational value of such encounters will become more important, not less, than in the past. A very substantial portion of our curriculum is enhanced by the discourse made possible by the various backgrounds of our students.....If our institutional capacity to bring together a diverse group of students is removed-or reducedthen the quality and texture of the education we provide will be diminished". (The New York Times, April 24, 1997, p. A27).Goodwin Liu (1998), offers a persuasive argument for "why, as a legal doctrine, educational diversity should qualify as a 'compelling interest' (p. 383). This manuscript argues for "placing the diversity rationale within the existing norm of equal protection doctrine.

5. It was also found that personal growth of students was increased, when they were exposed to multicultural situations (see, for example, Astin, (1977, 1993); Feldman and Newcomb, 1969; Pascarella and Terenzini, 1991).

6. Chang (1996) stated that that socializing across race and discussing racial/ethnic issues have a positive effect on students' retention, overall satisfaction with college, intellectual self-concept, and social self-concept. Bikson and Law (1994) argue that if colleges were meet the challenges presented by the global economy, they would have to change many areas (Bikson and Law, 1994).

7. There are four hidden benefits of diversity in higher education as stated by Kay Joseph (2014). These are easier graduation for non-blacks, less work for professors, helping instructors overcome bias, and creating a burgeoning middle class. 
8. It was also found that attending a higher quality college increased the wages of young men who attend them (Davis and Smith 1994).

9. There are several benefits of inclusion of diversity in higher education. American Council on Education (ACE) stated following benefits;

i. It enriches educational experiences

ii. It promotes personal growth and healthy society

iii. It strengths communities and corporations, and it enhances competitiveness

\subsection{Challenges for including diversity in Higher Education}

Many studies state different challenges related to the inclusion of diversity in higher education. Here is a glimpse of these studies

1. Student of color experience exclusion, isolation, alienation moreover, racism in universities when expose to multicultural education

2. Pascarella et al., (2012) stated that numerous studies have reported that women and minority faculty members are considerably less satisfied with many aspects of their jobs than are majority male faculty members

3. Multiple studies demonstrate that minority students often feel isolated and unwelcome in predominantly white institutions

4. The increasing cultural diversity in schools and classrooms weighs heavily on teachers, and one can say that the reality of the educational setting at present is one of increasing 'cultural mismatch' between teachers and their students on the one hand and between teachers and their students' parents on the contrary (Levinson 2009).

5. Cultural Pluralism is another challenge for the educational institution. Cultural Pluralism refers to an ethno-culturally diverse society. Surveys results showed a growing intolerance among nationals towards immigrants' presence and a loss of patience with immigrants' integration, which growing numbers of nationals consider to proceed too slowly (Heath \& Cheung, 2006).

6. There are several studies (Pedersen, 1997; Pettigrew 1998) that indicates teacher own concerns, attitudes and beliefs about cultural diversity is a major challenges in inclusion of diversity in higher education

7. The Role of administration and higher authorities is one of the major barriers for in promoting cultural diversity.

8. Studies indicated that indicates women students when they are minorities in their classes, experience unwelcoming climate that include sexist language, presentation of stereotype differential treatment from professors (American Council on Education (2012). 


\section{Conclusions}

As stated above there were five basic objectives of the study. Based on finding, conclusions were drawn

\section{Aims and objectives of Multicultural Education}

The first objective was related to aims and objectives of Multicultural Education. In this regards it was concluded that:

1. There is no agreement among researchers about the aims and objectives of multicultural education. Educational Theorist focuses on group culture and its development while Political theorist argued for multiculturalism.

2. the aims of cultural diversity is multifaceted like developing good citizens, correction of historical record Increase Self-esteem of nonmainstream students, Increase diversified student exposure, Preserve minority group culture, Foster children's autonomy, Promote Social Justice and Equity, Enable students to succeed in an integrated, multicultural world

\section{Benefits of inclusion diversity in higher education}

The second objective was to find out the benefits of cultural diversity in higher education. In this regard, it was concluded that

1. There are several studies which pointed out the benefits of cultural diversity in higher education for example Pascarella et al. (2001), Chang (1999), Kuh, Schuh, Whitt, and Associates (2009) identified many benefits of diversity

2. Similarly, American Association of Universities, Astin, (1977, 1993); Feldman and Newcomb, 1969; Pascarella and Terenzini, 1991), identified individual student growth and change due to diversity.

3. It was also concluded that diversity also has effects on student academic achievement. The studies showed that achievement increased with the increment of diversity and acceptance of cultural issues (Astin, 1993)

4. Scholars like Chang (1996); Bikson and Law (1994); Gurin (1999) identified three broad categories as an outcome of diversity viz citizenship engagement, racial/cultural engagement, and compatibility of differences. Studies also revealed that diversity has a positive effect on student retention.

5. Some researchers like Joseph (2014) describes some hidden benefits of diversity like overcome on the bias, broad mindedness and understanding of other cultures

\section{Challenges related to diversity}

The third objective was related to challenges associated with diversity. It was concluded that following challenges were faced 
1. Unacceptable behavior by other ethnical groups. Faculty members were also less satisfied. Especially women become a soft target for, and they are less satisfied.

2. Feeling of isolation due to cultural diversity.

3. Cultural mismatch between student and teachers and teachers and family. The cultural pluralism that reflects ethno-culturally diverse society also gives birth to intolerance in students.

4. Teachers own attitude towards acceptance and understanding of diversity is another problem. The problem is more multidimensional and powerful when it was unsupported by administration

5. Female minority student's acceptance in the class.

\section{Recommendations}

It was recommended that diversity is a reality so it is necessary that every member may take it as a matter of joy and accept it at every level. it can be done arranging different seminars and get together, celebrating different cultural days and making family visits. There is a need to review teacher education programs through the lens of diversity. Culturally responsive teaching and cultural acceptance may be helpful in overcoming the challenges related to diversity.

\section{References}

American Council on Education (2012) On the Importance of Diversity in Higher Education Retrieved on 22-12-15 from http://www.acenet.edu/newsroom/Documents/BoardDiversityStatement-June2012.pdf

Association of American Universities. (1997). On the importance of diversity in university admissions. The New York Times, April 24, A27. Retrieved on 4-1-16 from http://www.upenn.edu/almanac/v43/n35/aau.html

Athena Brand Wisdom (n.d) Semiotic Analysis Retrieved on 14-2-16 from http://www.athenabrand.com/what-we-do/semiotic-analysis

Banks, J. \& Banks, C. M. (1995). "Equity Pedagogy: An Essential Component of Multicultural Education." Theory into Practice 34:152-158.

Banks, J. (2009). The Routledge international companion to multicultural education. New York: Routledge.

Banks, J. A., \& Banks, C. A. (2004). Issues in Teacher Education and Practice 
In J. Banks (Ed.), Handbook of research on multicultural education. San Francisco, CA: Jossey-Bass Banks, J.A and Banks C. M. (2005). Improving Multicultural Education: Lessons from the Intergroup Education Movement. New York: Teachers College Press

Berry, J. Phinney, J. Sam, D., \& Vedder, P. (2006). Immigrant youth in cultural transition: Acculturation, identity, and adaptation across national contexts. NJ: Mahwah, Lawrence Erlbaum Associates

Bikson, T. K., \& Law, S. A. (1994). Global preparedness and human resources: College and corporate perspectives. Santa Monica, CA: Rand

Bowen, W. G., \& Bok, D. C. (1998). The shape of the river: Long-term consequences of considering race in college and university admissions. Princeton, NJ: Princeton University Press

Chang, M. J. (1999). Does racial diversity matter? The educational impact of a racially diverse Journal of College Student Development 40(4):377-395 • December 1969 Retrieved on 22-12-15

Cochran-Smith Banks James, Marilyn, Luis Moll, Anna Richert, Kenneth Zeichner, Pamela LePage, Linda Darling-Hammond and Helen Duffy with Morva McDonald (2005), Teaching Diverse Learners, in Preparing Teachers for a Changing World: What Teachers should learn and be able to do, eds. L. Darling-Hammond and J. BransfordSan Francisco: Jossey-Bass, 232-274.

Cockrell, K. S., Placier, P. L., Cockrell, D. H., \& Middle ton, J. N. (1999). Coming to terms with "diversity" and "multiculturalism" in teacher education: Learning about our students, changing our practice. Teaching and Teacher Education, 15, 351-366

Davis, J.A. \& Smith, T.R. (1994). General Social Survey [MRDF]. Chicago, IL: National Opinion Research

Feldman, K.A., \& Newcomb, T.M. (1969). The Impact of College on Students, Volume 1. San Francisco

Florio-Ruane, S. (1994). The future teachers' autobiography club: Preparing 
educators to support literacy learning in culturally diverse classrooms. English Education, 26(1), 52-66

Frankel Jack, R,. Wallen, Norman. E. \& Hyun, Helen. H. (2011). How to Design and Evaluate Research in Education New York: McGraw-Hill.

Gurin, P. (1999). Selections from the Compelling Need for Diversity in Higher Education, Expert Reports in Defense of the University of Michigan. UEEE Equity \& Excellence in Educ. Equity \& Excellence in Education, 32(2), 36-62. doi:10.1080/1066568990320207

Heath, A. \& Cheung, S (Eds.)(2006). Unequal chances; Ethnic minorities in Western labor markets. Oxford: Oxford University Press

Heffernan, C. (2001). The Irish Media and the Lack of Public Debate on New Reproductive Technologies (NRTs) in Ireland. Health: 5(3), 355-371. doi:10.1177/136345930100500305

Ibarra R, (2010). Context Diversity: Reframing Higher Education in the $21^{\text {st }}$ Century retrieved from http://compact.org/resource-posts/contextdiversity-reframing-higher-education-in- the-21st-century

Ibarra, R., (1999.) Multicontextuality: A New Perspective on Minority Underrepresentation in SEM Academic Fields, Research News on Minority Graduate Education. Making Strides, (American Association for the Advancement of Science). 1(3), 1-9

Ibarra, R.. (1999). Studying Latinos in a "Virtual" University: Reframing Diversity and Academic Culture Change. Julian Samora Research Institute, Occasional Paper, No. 48, October, proceedings from Latinos, the Internet, and the Telecommunication Revolution, East

Johnson, L., \& Joshee, R. (2007). Multicultural education policies in Canada and the United States. Vancouver: UBC Press

Joseph K (2014), The hidden benefits of diversity in higher education American Renaissance, July Retrieved from http://www.amren.com/news/2014/07/the-hidden-benefits-of-diversityin- higher-education/ 
Joshee R, Sihra K., (2009.). Religion Culture and Language in India. In The Rutledge International Companion to Multicultural Education. Sage

Kuh, G., Schuh, J.S., Whitt, E.J., Andreas, R.E., Lyons, J.W., Strange, C.C., Krehbiel, L.E., \& MacKay, K.A. (1991). Involving colleges: Successful approaches to fostering student learning and personal development outside the classroom. San Francisco: Jossey-Bass.

Labs, C (2011). Administration Methods' Modified 7 October 2011, Retrieved on $12-2-16$

https://www.studentvoice.com/app/wiki/Methods\%20of\%20Assessment $\%$ 20Distribution. ashx?NoRedirect $=1$

Levinson, M. (2009). 'Mapping Multicultural Education' in Harvey Seigel, ed., The Oxford Handbook of Philosophy of Education (Oxford University Press)

Liu, G. (1998). Affirmative Action in Higher Education: The Diversity Rationale and the Compelling Interest Test. Harvard Civil Rights-Civil Liberties Law Review. 33, 381-442.

Milem, J.F. (2003). The educational benefits of diversity: Evidence from multiple sectors.In M. Chang, D. Witt, J. Jones, \& K. Hakuta (Eds.). Compelling Interest: Examining the evidence on racial dynamics in higher education. Palo Alto, CA: Stanford University Press, 126-169 on 14-2-16 from http://faculty.ucmerced.edu/khakuta/policy/racial_dynamics/Chapter5.pd $\mathrm{f}$

Pascarella, E. T., \& Terenzini, P. T. (1991). How college affects students. San Francisco: Jossey- Bass.

Pedersen, P. (1997). Culture-centered counseling interventions. Thousand Oaks: Sage Pettigrew, T.(1998). Reactions to the new minorities of Western Europe. Annual Review of Sociology, 24, 77-103. Publications

Sleeter, C. E., \& Grant, C. A. (2007). Making choices for multicultural education: Five approaches to race, class, and gender New York Merrill Publishing Company 
International Journal of Innovation in Teaching and Learning (IJITL)

Volume II- Issue II (December 2016)

Smith, P. B. \& Bond, M. H. (1998). Social Psychology across Cultures. London, Prentice Hall Europe

Tanaka, G. K. (1996). The Impact of Multiculturalism on White Students (Unpublished Ph.D. dissertation), University of California, Los Angeles. 